\title{
microorganisms
}

ISSN 2076-2607

www.mdpi.com/journal/microorganisms

Article

\section{Cold-Active, Heterotrophic Bacteria from the Highly Oligotrophic Waters of Lake Vanda, Antarctica}

\section{Nicole A. Vander Schaaf ${ }^{1, \dagger}$, Anna M. G. Cunningham ${ }^{1}$, Brandon P. Cluff ${ }^{2}$,}

CodyJo K. Kraemer ${ }^{2,}$, Chelsea L. Reeves ${ }^{1, \S}$, Carli J. Riester ${ }^{1, £}$, Lauren K. Slater ${ }^{1}$, Michael T. Madigan ${ }^{3}$ and W. Matthew Sattley ${ }^{1, *}$

1 Division of Natural Sciences, Indiana Wesleyan University, 4201 South Washington St., Marion, IN 46953-4974, USA; E-Mails: Nicole.VanderSchaaf@vai.org (N.A.V.S.); annamgcunningham@hotmail.com (A.M.G.C.); chelsealreeves@gmail.com (C.L.R.); carlijriester@trevecca.edu (C.J.R.); laurenkayslater@gmail.com (L.K.S.)

2 Department of Biology, MidAmerica Nazarene University, 2030 E. College Way, Olathe, KS 66062, USA; E-Mails: brandonpcluff@gmail.com (B.P.C.); ckraemer@email.arizona.edu (C.K.K.)

3 Department of Microbiology, Southern Illinois University, 1125 Lincoln Dr., Carbondale, IL 62901, USA; E-Mail: madigan@micro.siu.edu

$\dagger$ Present addresses: Van Andel Research Institute, Grand Rapids, MI 49503, USA.

$\$$ Present addresses: Department of General Surgery, University of Arizona Medical Center, Tucson, AZ 85724, USA.

$\S$ Present addresses: Boonshoft School of Medicine, Wright State University, Dayton, OH 45435, USA.

$£$ Present addresses: Graduate Physician Assistant Program, Trevecca Nazarene University, Nashville, TN 37210, USA.

* Author to whom correspondence should be addressed; E-Mail: matthew.sattley@indwes.edu; Tel.: +1-765-677-2128; Fax: +1-765-677-2455.

Academic Editors: Ricardo Amils and Elena González Toril

Received: 12 June 2015 / Accepted: 9 July 2015 / Published: 24 July 2015

Abstract: The permanently ice-covered lakes of the McMurdo Dry Valleys, Antarctica are distinctive ecosystems that consist strictly of microbial communities. In this study, water 
samples were collected from Lake Vanda, a stratified Dry Valley lake whose upper waters (from just below the ice cover to nearly $60 \mathrm{~m}$ ) are highly oligotrophic, and used to establish enrichment cultures. Six strains of psychrotolerant, heterotrophic bacteria were isolated from lake water samples from a depth of 50 or $55 \mathrm{~m}$. Phylogenetic analyses showed the Lake Vanda strains to be species of Nocardiaceae, Caulobacteraceae, Sphingomonadaceae, and Bradyrhizobiaceae. All Lake Vanda strains grew at temperatures near or below $0{ }^{\circ} \mathrm{C}$, but optimal growth occurred from 18 to $24{ }^{\circ} \mathrm{C}$. Some strains showed significant halotolerance, but no strains required $\mathrm{NaCl}$ for growth. The isolates described herein include cold-active species not previously reported from Dry Valley lakes, and their physiological and phylogenetic characterization broadens our understanding of these limnologically unique lakes.

Keywords: Antarctica; Lake Vanda; McMurdo Dry Valleys; psychrotolerant; halotolerant

\section{Introduction}

Lake Vanda is a stratified lake about $75 \mathrm{~m}$ deep located in Wright Valley of the McMurdo Dry Valleys, Antarctica, a region that experiences subzero average temperatures and extremely low $(\sim 10 \mathrm{~mm})$ annual precipitation [1]. As in other Dry Valleys lakes, metazoans and other more complex eukaryotic organisms are absent from Lake Vanda, and therefore biological processes in the lake are driven entirely by the activities of microorganisms. In addition, microorganisms inhabiting the lake are isolated from their surroundings by a permanent ice cover of approximately $3.5 \mathrm{~m}$, which limits the penetration of light and inhibits wind mixing of the water column. As a result, the meromictic water column exhibits distinct vertical clines with defined zones of primary productivity [2].

The waters of Lake Vanda range from fresh and cold $\left(\sim 4^{\circ} \mathrm{C}\right)$ just below the ice cover to hypersaline and surprisingly warm $\left(\sim 24{ }^{\circ} \mathrm{C}\right)$ just above the sediments (Figure 1). At depths of $50-55 \mathrm{~m}$, Lake Vanda waters are approximately $10-12{ }^{\circ} \mathrm{C}$ with a $\mathrm{pH}$ of $6.5-7$ [3]. Levels of dissolved organic carbon (DOC) in Lake Vanda are quite low $\left(<0.2 \mathrm{mg} \cdot \mathrm{C} \cdot \mathrm{L}^{-1}\right)$ down to about $60 \mathrm{~m}$, and salinity is nearly undetectable to a depth of $55 \mathrm{~m}$ [4,5] (Figure 1). In addition, the lake is supersaturated with dissolved $\mathrm{O}_{2}$ to a depth of about $65 \mathrm{~m}$ [3], beyond which salinity, temperature, and sulfide increase to the sediments (Figure 1).

Compared to temperate aquatic ecosystems, our knowledge of microbial life in the permanently cold Dry Valleys lakes of Antarctica remains limited. Limnological and physicochemical properties of these unusual lakes have been well studied and have linked biogeochemical nutrient cycling to the activities and distributions of various microorganisms [2,3,6-15]. Although several studies have focused on the enrichment and isolation of bacteria from lakes in the Dry Valleys [16-22], few descriptions of bacterial isolates from Lake Vanda exist. Decades-old studies on the microbial communities of Lake Vanda reported the successful culture of some bacteria and even yeasts from Lake Vanda [23-26]; however, phylogenetic analyses were not included in these descriptions. More recently, Bratina et al. [27] described cultures of manganese-reducing bacteria, mostly of the genus Carnobacterium, from oxic portions of the Lake Vanda water column, and Tregoning et al. [28] 
described $\mathrm{CaCl}_{2}$-tolerant, halophilic bacteria isolated from the comparatively warm Lake Vanda brines of 60-72 m. In the latter study, the 15 mesophilic strains obtained comprised a single species most closely related to the aerobic marine $\gamma$-proteobacterium Halomonas zincidurans.

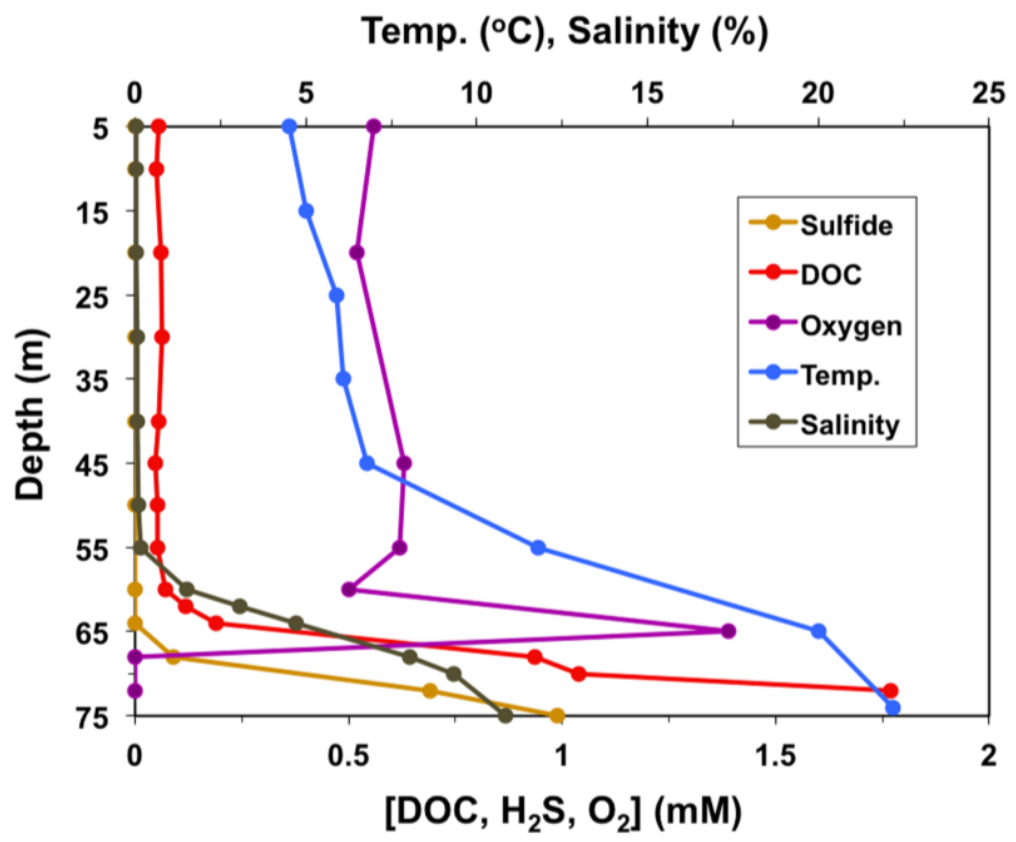

Figure 1. Physiochemical profile of the Lake Vanda water column. Due to the permanent ice cover on Lake Vanda, measurements begin at a depth of $5 \mathrm{~m}$.

We have employed culture-based methods to obtain new isolates of heterotrophic bacteria from the cool and oligotrophic upper waters of Lake Vanda. Our analyses reveal species not previously recognized from any Dry Valley lake (including Lake Vanda) and compare these cold-active strains to previously described Dry Valley lake species. The halotolerant and psychrotolerant chemoorganotrophic bacteria described here grew well under the physiochemical conditions of their habitat and, therefore, likely contribute to DOC degradation and nutrient cycling in the water column of Lake Vanda.

\section{Materials and Methods}

\subsection{Sample Collection and Analysis, Enrichment, and Isolation}

Lake Vanda water samples were obtained at coordinates $77^{\circ} 31.685^{\prime} \mathrm{S} / 161^{\circ} 35.425^{\prime} \mathrm{E}$ by using a gasoline-powered drill head fitted with joined sections of a 10-inch $(25.4 \mathrm{~cm})$ steel auger to create the sampling hole in the $\sim 3.5$-m lake ice cover. Water samples were collected in a 5 L Niskin sampling bottle and transferred to completely filled PVC or polycarbonate Nalgene ${ }^{\mathrm{TM}}$ bottles that had been previously washed with a $10 \%(\mathrm{v} / \mathrm{v}) \mathrm{HCl}$ solution and thoroughly rinsed with distilled water. All samples were kept cold $\left(\sim 4{ }^{\circ} \mathrm{C}\right)$ but unfrozen in darkness from the time of their collection. Water column sulfide concentrations were determined as previously described [11] using the methylene blue colorimetric method of Trüper and Schlegel [29]. Additional physiochemical properties of the Lake Vanda water column were obtained from the National Science Foundation-funded McMurdo Long-Term Ecological Research Program online database [30]. 
Primary enrichment cultures were established by aseptically spreading $0.1 \mathrm{~mL}$ Lake Vanda water from a depth of 50 or $55 \mathrm{~m}$ onto petri dishes containing R2A agar (pH 7.2) [31] or Bacto Plate Count Agar [32]. Incubations took place in darkness at $4{ }^{\circ} \mathrm{C}, 8{ }^{\circ} \mathrm{C}$, or room temperature $\left(\sim 22{ }^{\circ} \mathrm{C}\right)$. Colonies selected for isolation were purified by at least three successive platings. Isolated strains were transferred to and maintained in loosely screw-capped $10-\mathrm{mL}$ tubes containing $3 \mathrm{~mL}$ of either a defined ammonium glucose medium (described below) or liquid medium R2A and incubated at $4-18{ }^{\circ} \mathrm{C}$. To ensure sufficient $\mathrm{O}_{2}$ in cell suspensions, liquid cultures of isolated strains were mixed several times per week.

The ammonium glucose medium contained the following per liter of double-distilled water: glucose, $10 \mathrm{~g} ; \mathrm{NH}_{4} \mathrm{Cl}, 1 \mathrm{~g} ; \mathrm{KH}_{2} \mathrm{PO}_{4}, 0.5 \mathrm{~g} ; \mathrm{KCl}, 0.2 \mathrm{~g} ; \mathrm{MgSO}_{4} \cdot 7 \mathrm{H}_{2} \mathrm{O}, 0.2 \mathrm{~g} ; \mathrm{CaCl}_{2} \cdot 2 \mathrm{H}_{2} \mathrm{O}, 0.05 \mathrm{~g}$; and yeast extract, $0.01 \mathrm{~g}$. All chemicals were reagent grade and obtained from Sigma-Aldrich, Co., St. Louis, MO or J.T. Baker Chemical Co., Phillipsburg, NJ, USA.

\subsection{Morphology}

Morphological determinations were made using a Leica Microsystems Model DM1000 phase-contrast light microscope, and high-resolution imaging was done on an FEI NOVA nanoSEM field emission scanning electron microscope (FEI Company, Hillsboro, OR, USA). Capsule stains were performed using the method of Maneval [33]. Motility was determined by microscopic observations and from assessing stab inoculations into semi-solid ( $0.35 \%$ agar $)$ sulfide-indole-motility (SIM) medium (Becton, Dickinson and Company, Sparks, MD, USA) [32].

\subsection{Physiological Studies}

To determine the cardinal growth temperatures for isolated strains, triplicate $10-\mathrm{mL}$ tubes of liquid medium R2A were inoculated and incubated for seven days at temperatures ranging from $-2{ }^{\circ} \mathrm{C}$ to $37^{\circ} \mathrm{C}$; growth was assessed turbidimetrically. Growth rates were measured by periodic turbidity readings of cultures grown in the same way. Salinity tolerance was determined using liquid R2A media containing various levels of $\mathrm{NaCl}$; cultures were incubated at $15{ }^{\circ} \mathrm{C}$ and visually inspected for turbidity for up to one month.

The ammonium glucose medium described above was used to test the utilization of various carbon sources. In these experiments, glucose was substituted with a variety of single carbon sources or yeast extract. Inoculated tubes were incubated at $15{ }^{\circ} \mathrm{C}$ for 10 days before scoring for growth. The potential for anaerobic growth was tested in all strains using anoxic media containing either dimethyl sulfoxide, sodium nitrate, or sodium fumarate (each at a final concentration of $10 \mathrm{mM}$ ) as an alternative electron acceptor. To achieve anoxic conditions, $1.2 \mathrm{mM}$ (final) sodium sulfide was added to R2A media containing resazurin as redox indicator before being dispensed into completely filled screw-cap tubes, inoculated, and incubated at $15^{\circ} \mathrm{C}$ for one month.

The potential for phototrophic growth of strain VP55 was tested in completely filled $150-\mathrm{mL}$ bottles containing the following medium (per liter of double-distilled water): ethylenediaminetetraacetic acid (EDTA), $10 \mathrm{mg} ; \mathrm{MgSO}_{4} \cdot 7 \mathrm{H}_{2} \mathrm{O}, 0.2 \mathrm{~g} ; \mathrm{CaCl}_{2} \cdot 2 \mathrm{H}_{2} \mathrm{O}, 0.075 \mathrm{~g} ; \mathrm{NH}_{4} \mathrm{Cl}, 0.75 \mathrm{~g} ; \mathrm{NaCl}, 1 \mathrm{~g} ; \mathrm{Na}_{2} \mathrm{~S}_{2} \mathrm{O}_{3} \cdot 5 \mathrm{H}_{2} \mathrm{O}$, $0.1 \mathrm{~g}$; sodium succinate, $2.0 \mathrm{~g}$; sodium pyruvate, $0.5 \mathrm{~g}$; sodium acetate, $0.5 \mathrm{~g}$; yeast extract, $0.5 \mathrm{~g}$; vitamin $\mathrm{B}_{12}, 20 \mu \mathrm{g}$; trace elements [34], $1 \mathrm{~mL}$; and $\mathrm{K}_{2} \mathrm{HPO}_{4}, 1 \mathrm{~g}$. Cultures were incubated for six weeks at $15^{\circ} \mathrm{C}$ at four different incandescent light intensities before being scored for growth. 
Starch hydrolysis was tested in complex media containing 1\% (wt/vol) soluble starch [32]. SIM medium was used to test for indole formation by tryptophanase and also for sulfide production via cysteine desulfurase and/or thiosulfate reductase [32]. The possibility of gelatinase and urease synthesis was tested in complex nutrient media containing gelatin $(40 \mathrm{~g} / \mathrm{L})$ or urea $(20 \mathrm{~g} / \mathrm{L})$, respectively [32].

\subsection{Phylogenetic Analyses}

Genomic DNA was isolated from mid-log-phase cells, and small-subunit (16S) rRNA gene sequences were PCR amplified as previously described [16]. Controls containing no DNA were included in all PCR reactions, and 16S rRNA gene amplification products were confirmed to be of proper size ( $1500 \mathrm{bp})$ by comparison to a $1 \mathrm{~Kb}$ DNA Ladder (Invitrogen, Carlsbad, CA, USA). Bacterial DNA from each strain was purified from gels using the QIAquick Gel Extraction Kit (QIAGEN Sciences, Germantown, MD, USA) according to the manufacturer's instructions.

Sequence fragments of purified 16S rRNA genes were assembled, and multiple alignments were generated using UGENE version 1.11.0 [35], MUSCLE [36], and MEGA version 5.05 [37]. Positions with gaps or missing data were eliminated from each analysis. Phylogenetic relationships were determined using BLAST [38], sequence analysis functions of the Ribosomal Database Project [39], and the List of Prokaryotic names with Standing in Nomenclature [40]. MEGA5 was used to create maximum-likelihood phylogenetic trees with 1000 bootstrap replications using the Tamura-Nei distance correction model and the Nearest-Neighbor-Interchange (NNI) heuristic method [41].

Small-subunit rRNA gene sequences from the six strains of Lake Vanda bacteria isolated in this study were deposited into GenBank under the accession numbers shown in the phylogenetic tree figures. Cultures of the Lake Vanda isolates were preserved at $-80{ }^{\circ} \mathrm{C}$ in growth medium containing $10 \%$ (final) dimethyl sulfoxide (DMSO) and are available from the corresponding author upon written request.

\section{Results}

\subsection{Isolation and Morphology of Lake Vanda Strains}

After a two-week incubation at temperatures ranging from $4{ }^{\circ} \mathrm{C}$ to room temperature, both pigmented and unpigmented colonies developed on plates of enrichment media inoculated with Lake Vanda water from depths of 50 or $55 \mathrm{~m}$. Six strains that grew well were isolated in pure culture from these colonies and selected for further study.

When grown on plates of medium R2A, colonies of strain BYV50 appeared bright yellow to orange, strain VP55 was pink, strain VY55 was bright yellow, and strains VS55, VW50, and VW55 were not pigmented (Table 1). Colonies of five of the strains had entire margins, convex elevation, a smooth surface, opaqueness, and circularity; by contrast, colonies of strain VP55 were translucent and punctiform. Strains BYV50 and VP55 were nonmotile rods, whereas cells of strain VY55 were highly motile rods that appeared as single cells, short chains, or occasionally as rosettes of several cells tethered together. Cells of strains VW50, VW55, and VS55 were highly motile, short rods that were often arranged in rosettes of 8-15 cells. The major phenotypic properties of the Lake Vanda strains are shown in Table 1, and photomicrographs of all strains are shown in Figures 2A and 3A. 
Table 1. Summary of major properties of Lake Vanda bacteria isolated in this study ${ }^{\text {a }}$.

\begin{tabular}{ccccc}
\hline Property & $\begin{array}{c}\text { Rhodococcus sp. } \\
\text { BYV50 }\end{array}$ & $\begin{array}{c}\text { Brevundimonas spp. VW50, } \\
\text { VW55, and VS55 }\end{array}$ & $\begin{array}{c}\text { Bradyrhizobiaceae sp. } \\
\text { VP55 }\end{array}$ & $\begin{array}{c}\text { Sphingobium sp. } \\
\text { VY55 }\end{array}$ \\
\hline Cell shape & Straight rod & Straight-to-curved rod & $\begin{array}{c}\text { Straight rod, often } \\
\text { tapered }\end{array}$ & Straight rod \\
\hline $\begin{array}{c}\text { Motility } \\
\text { Cell size } \\
(1 \times \mathrm{w}, \mu \mathrm{m})\end{array}$ & - & + & - & + \\
$\begin{array}{c}\text { Gram stain } \\
\text { reaction }\end{array}$ & $2-5 \times 1-1.2$ & $1.4-3.2 \times 0.7-0.8$ & $1.5-3.5 \times 0.9-1.1$ & $1.8-8 \times 0.9-1$ \\
$\begin{array}{c}\text { Pigment } \\
\text { Bright yellow/ } \\
\text { Orange }\end{array}$ & - & - & - \\
\hline $\begin{array}{c}\text { Temp. range } \\
\left({ }^{\circ} \mathrm{C}\right)\end{array}$ & $-2-32$ & None & Pink & Bright yellow \\
$\begin{array}{c}\text { Temp. optimum } \\
\left({ }^{\circ} \mathrm{C}\right)\end{array}$ & $18-24$ & $-2-35$ & $2-29$ & $0-30$ \\
$\begin{array}{c}\text { Salinity range } \\
(\% \mathrm{NaCl})\end{array}$ & $0-10$ & 20 & 20 & 20 \\
\hline
\end{tabular}

a Maneval's staining showed that all strains were encapsulated. The $\mathrm{KOH}$ string test [42] was used to verify the Gram reactions of strains that showed ambiguous Gram stain results. Photomicrographs of all strains are shown in Figures 2 and 3.

\subsection{Phylogeny}

Phylogenetic analyses showed the six strains of Lake Vanda bacteria belong to four distinct phylogenetic lineages. BLAST searches indicate strain BYV50 is a species of the genus Rhodococcus, strain VP55 is of the family Bradyrhizobiaceae and aligns most closely with the genus Rhodopseudomonas, strain VY55 is a species of Sphingobium, and strains VW50, VS55, and VW55 are species of the genus Brevundimonas.

Strain BYV50 showed 100\% 16S rRNA gene sequence identity to Arctic seawater bacterium R7851 and $99.9 \%$ identity to three other Rhodococcus species, all of Arctic or Antarctic origin (Figure 2B). Strains VW55, VW50, and VS55 showed 100\% 16S rRNA gene sequence identity to each other and to several additional Brevundimonas strains, including Mediterranean Sea bacterium Brevundimonas mediterranea str. V4.BO.18 (Figure 3B). In the same analysis, strain VP55 showed $99.4 \%$ identity to legume-associated Rhodopseudomonas sp. ORS 1416ri and Rhodopseudomonas sp. R-45977. Strain VY55 had an identical 16S rRNA gene sequence to Antarctic Sphingobium spp. FO10 and a 99.3\% identity to Antarctic isolate Sphingomonas sp. Ant17 (Figure 3B).

\subsection{Physiology}

All Lake Vanda strains grew aerobically on medium R2A. With the exception of strain VP55, which did not grow on any sugar or alcohol tested, all strains were capable of using a range of carbon sources to support growth, and yeast extract supported good growth of all strains (Table 2). Anaerobic growth was not observed in any cultures, either by fermentation of glucose or anaerobic respiration in anoxic medium R2A supplemented with commonly used alternative electron acceptors, including 
dimethyl sulfoxide, nitrate, or fumarate (10 mM each). Moreover, sulfur reduction was not observed in tubes of SIM medium, which contains both ferrous ammonium sulfate and sodium thiosulfate.

A
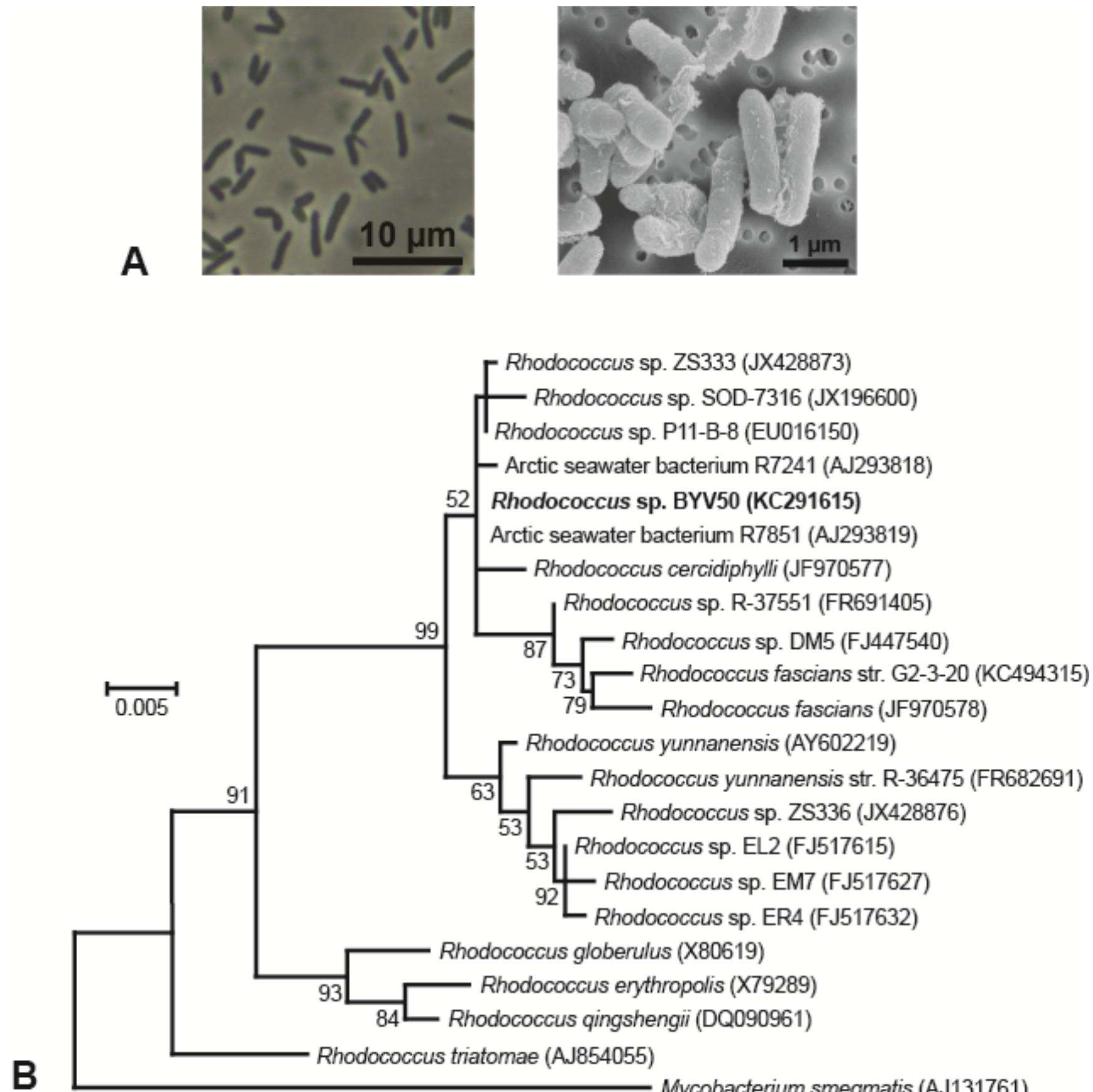

Figure 2. Morphology and phylogeny of Rhodococcus strain BYV50. (A) Phase-contrast micrograph (left) and scanning electron micrograph (right) showing cell morphology and arrangement; (B) Phylogenetic tree generated from 1435 nucleotide positions of the 16S rRNA gene. Mycobacterium smegmatis is the outgroup organism, and bootstrap values $>50 \%$ are shown at the branching points. GenBank accession numbers are listed in parentheses. 
A

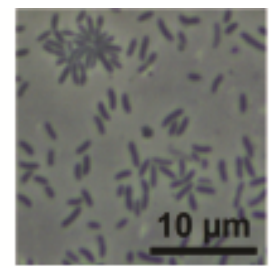

VW55

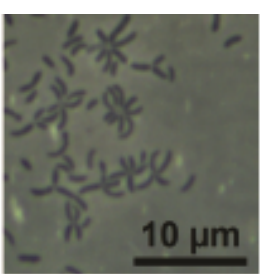

VS55

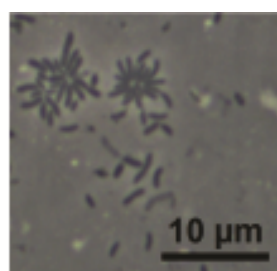

VW50

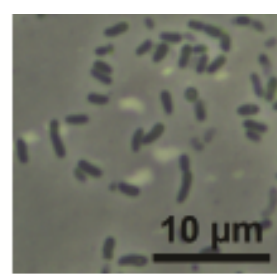

VP55

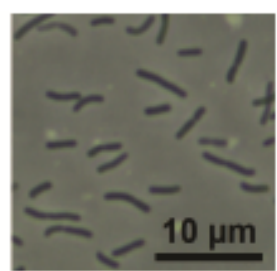

VY55

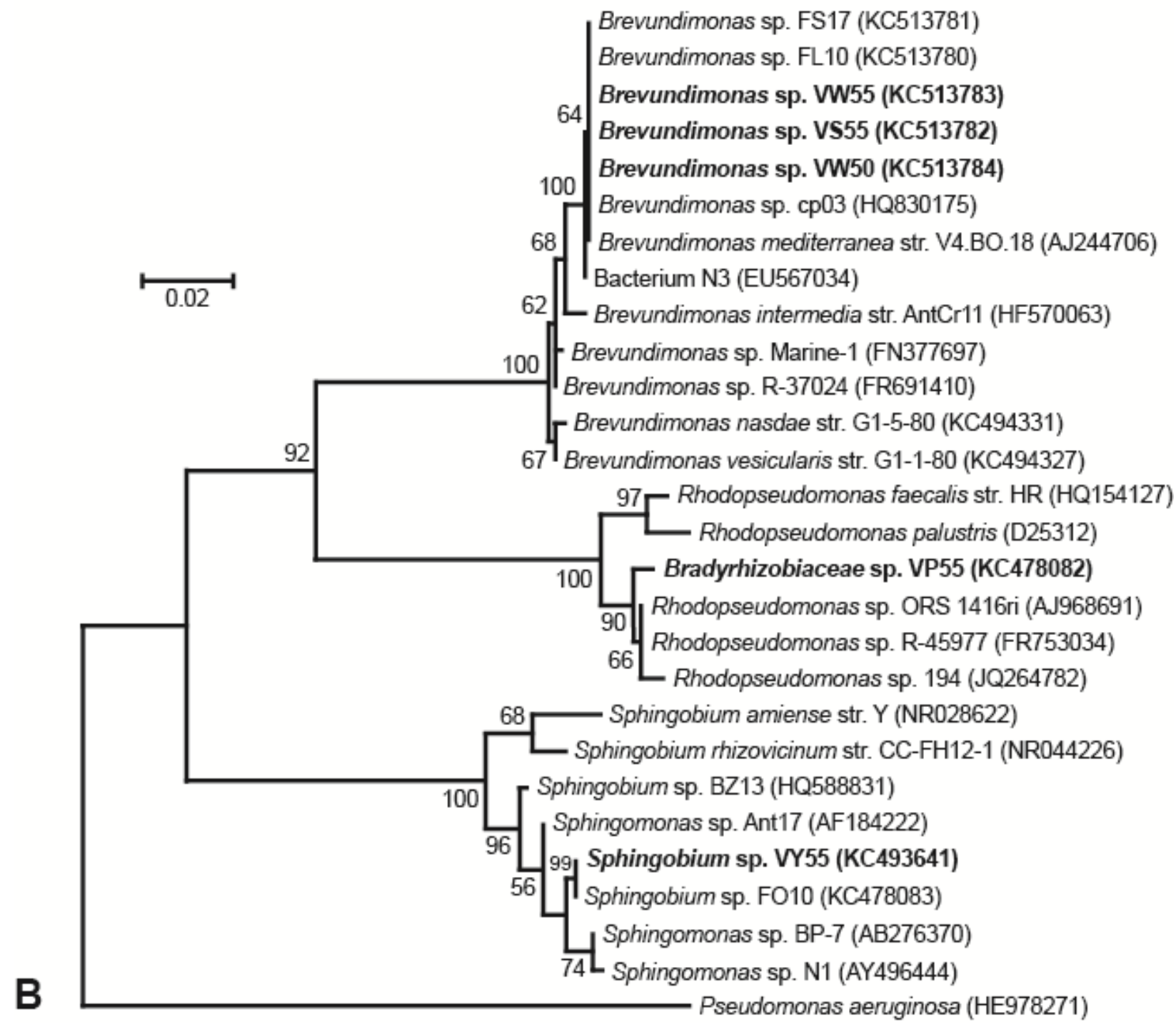

Figure 3. Morphology and phylogeny of gram-negative Lake Vanda isolates. (A) Phase-contrast photomicrographs showing cell morphology and arrangement of each strain; (B) Phylogenetic tree generated from 1369 nucleotide positions of the 16S rRNA gene. Pseudomonas aeruginosa is the outgroup organism, and bootstrap values $>50 \%$ are shown at the branching points. GenBank accession numbers are listed in parentheses. 
Table 2. Carbon source utilization by Lake Vanda bacteria isolated in this study ${ }^{\text {a }}$.

\begin{tabular}{|c|c|c|c|c|}
\hline $\begin{array}{l}\text { Carbon } \\
\text { Source } \\
\end{array}$ & $\begin{array}{c}\text { Rhodococcus sp. } \\
\text { BYV50 }\end{array}$ & $\begin{array}{l}\text { Brevundimonas spp. } \\
\text { VW50, VW55, VS55 }\end{array}$ & $\begin{array}{c}\text { Bradyrhizobiaceae sp. } \\
\text { VP55 }\end{array}$ & $\begin{array}{c}\text { Sphingobium sp. } \\
\text { VY55 }\end{array}$ \\
\hline \multicolumn{5}{|c|}{ SUGARS } \\
\hline Glucose & + & + & - & $(+)$ \\
\hline Fructose & ++ & $(+)$ & - & - \\
\hline Ribose & + & $(+)$ & - & - \\
\hline Galactose & + & + & - & $(+)$ \\
\hline Sucrose & ++ & - & - & $(+)$ \\
\hline Maltose & + & + & - & $(+)$ \\
\hline Lactose & + & $(+)$ & - & $(+)$ \\
\hline Xylose & ++ & - & - & - \\
\hline Mannose & + & $(+)$ & - & - \\
\hline \multicolumn{5}{|c|}{ ALCOHOLS } \\
\hline Ethanol & + & + & - & $(+)$ \\
\hline Propanol & ++ & $(+)$ & - & - \\
\hline \multicolumn{5}{|c|}{ FATTY AND ORGANIC ACIDS } \\
\hline Acetate & + & + & - & $(+)$ \\
\hline Pyruvate & + & + & + & $(+)$ \\
\hline Propionate & ++ & - & - & - \\
\hline Butyrate & ++ & + & $(+)$ & $(+)$ \\
\hline Lactate & ++ & + & + & - \\
\hline Fumarate & + & + & - & - \\
\hline Succinate & ++ & + & $(+)$ & $(+)$ \\
\hline Benzoate & + & - & - & - \\
\hline Yeast Extract & ++ & ++ & + & + \\
\hline
\end{tabular}

a Growth was assessed as the difference of the time zero absorbance $\left(\mathrm{OD}_{540}\right)$ from the final absorbance using the following scale:,$++ \Delta \mathrm{OD}_{540}>0.15 ;+, \Delta \mathrm{OD}_{540}$ 0.051-0.150; $(+), \Delta \mathrm{OD}_{540}$ 0.021-0.050; -, $\Delta \mathrm{OD}_{540}$ 0-0.02. Carbon sources had the following final concentrations: yeast extract, $0.1 \%$; benzoate, lactose, $3 \mathrm{mM}$; maltose, sucrose, fructose, glucose, galactose, butyrate, succinate, $5 \mathrm{mM}$; all others, $10 \mathrm{mM}$. No strains grew with malate or citrate (10 mM each) as sole carbon source, and only strain BYV50 was capable of degrading urea. All strains tested negative for tryptophanase, gelatinase, cysteine desulfurase, and starch hydrolysis.

All Lake Vanda strains grew at the temperatures of their habitat. The Brevundimonas strains and Rhodococcus str. BYV50 grew within a broad temperature range and were capable of slow growth at $-2{ }^{\circ} \mathrm{C}$ (Table 1 and Figure 4). The other Lake Vanda strains showed a lesser degree of cold adaptation; growth at $0{ }^{\circ} \mathrm{C}$ was very slow for strain VY55 and did not occur for strain VP55. Whereas all strains showed cold adaptation to varying degrees, optimal growth of all strains occurred near $20{ }^{\circ} \mathrm{C}$ (Table 1). Rhodococcus str. BYV50 had a fairly wide optimal temperature range, as robust growth occurred from 18 to $24{ }^{\circ} \mathrm{C}$ (Figure 4). The Brevundimonas strains had a maximum growth temperature of $35{ }^{\circ} \mathrm{C}$, and therefore these strains showed the widest growth temperature range. Strains BYV50 and VY55 were capable of growth up to $32{ }^{\circ} \mathrm{C}$ and $30{ }^{\circ} \mathrm{C}$, respectively, and strain VP55 grew within the narrowest temperature range of $2-29^{\circ} \mathrm{C}$. 

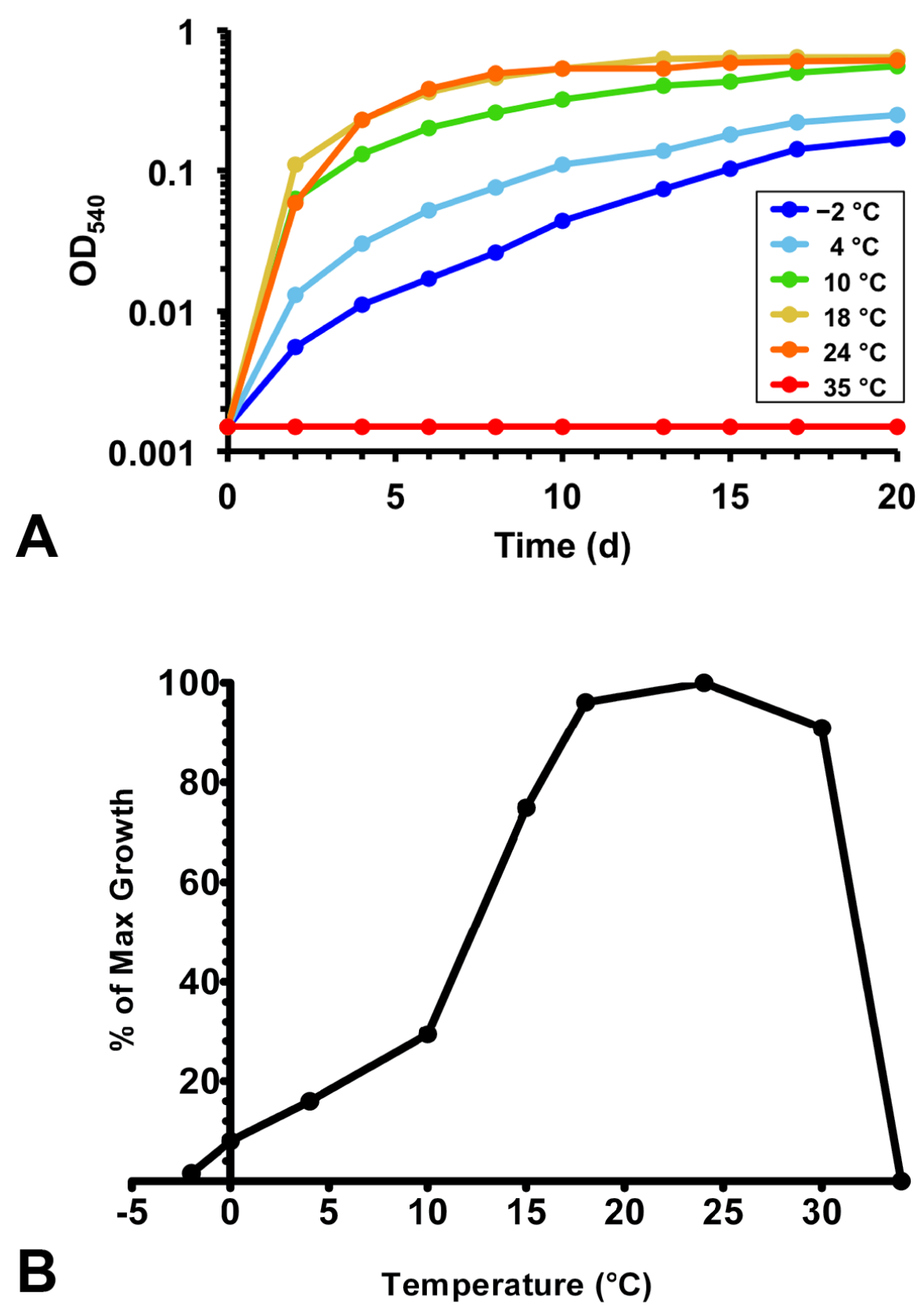

Figure 4. Growth response to temperature for Lake Vanda strain BYV50. (A) Growth of strain BYV50 over a range of temperatures in medium R2A containing $0.5 \% \mathrm{NaCl}$. Slow growth at $-2{ }^{\circ} \mathrm{C}$ occurred, while no growth was observed at $35{ }^{\circ} \mathrm{C}$; (B) Expression of growth rate data as percent maximum growth. Optical densities for triplicate cultures at each temperature were averaged following growth for seven days. The highest density was assigned a value of 100 , and the percentage of maximum growth was calculated for each remaining temperature.

The Lake Vanda strains showed a wide range of salinity tolerances. While none of the Lake Vanda isolates had a $\mathrm{NaCl}$ requirement, the addition of $0.5 \% \mathrm{NaCl}$ (final) to culture media stimulated growth of all strains, and several strains showed at least a moderate degree of halotolerance. Strain BYV50 was strongly halotolerant and could grow in media containing up to $10 \% \mathrm{NaCl}$. The Brevundimonas and 
Sphingobium strains were less halotolerant and grew in media containing up to $6 \% \mathrm{NaCl}$. By contrast, strain VP55 was quite salt sensitive and failed to grow in media containing more than $1 \% \mathrm{NaCl}$.

\section{Discussion}

Our phylogenetic analyses showed the Lake Vanda strains to be species of Nocardiaceae, Caulobacteraceae, Sphingomonadaceae, and Bradyrhizobiaceae; these bacterial families contain primarily aquatic or terrestrial bacteria. It is therefore of interest to consider the origin of these isolates since they are removed from the "external environment" by nearly four meters of permanent ice cover.

Most of the Lake Vanda strains showed a close phylogenetic relationship to bacteria obtained from diverse Antarctic and non-Antarctic ecosystems. For example, Rhodococcus sp. BYV50 showed 100\% 16S rRNA gene sequence identity to Arctic seawater bacterium R7851 isolated from the Western Greenland Sea [43]. Like the plant pathogen Rhodococcus fascians, strains BYV50 and R7851 are Gram positive and display yellow-to-orange pigmentation [43]. Other Rhodococcus species related to Rhodococcus sp. BYV50 were isolated from Antarctica, including $R$. cercidiphylli from an ice core obtained from central Dronning Maud Land [44] and Antarctic seawater bacterium R7241 from sites above the Gunnerus and Astrid Ridges [43]. The pervasive polar distribution of these closely related Rhodococcus strains suggests they may be important contributors to organic carbon degradation in cold, oligotrophic waters.

Phylogenetic analyses of the Brevundimonas strains showed $100 \%$ identity to each other and to several other Brevundimonas strains, including B. mediterranea str. V4.BO.18 and Brevundimonas sp. cp03. The latter strains were isolated from the northwestern basin of the Mediterranean Sea [45] and a magnetite mine drainage sample near an iron mine in the Hebei Province of China [46], respectively. It therefore appears that this versatile Brevundimonas species, which includes strains ranging from Antarctic lakes to the Mediterranean Sea, has a widespread and diverse aquatic distribution.

Lake Vanda strain VP55 formed translucent, pink colonies consisting of nonmotile, short rods that often had a tapered appearance. This isolate showed 99.4\% identity to both Rhodopseudomonas sp. ORS 1416ri, isolated from legume root nodules in Tunisia [47], and Rhodopseudomonas sp. R-45977, rhizobia isolated from legumes in Belgium [48]. This connection is peculiar since the permanently cold Dry Valleys lakes support solely microbial life and would therefore not be expected to harbor strains so closely related to bacteria that develop mutualistic associations with plants. More in line with the ecophysiology of strain VP55, BLAST searches also revealed a close phylogenetic relationship of this organism to Rhodopseudomonas sp. 194, a bacterium isolated from an ice core. A formal description of strain 194 has not been published, and thus its physiology and exact habitat are unclear.

Despite its phylogenetic association with species of the purple bacterium Rhodopseudomonas, such as $R$. palustris, strain VP55 did not show the pigmented photoheterotrophic growth typical of purple nonsulfur bacteria [49] when incubated for six weeks in the light in an anoxic medium containing acetate, pyruvate, and succinate. Moreover, a spectral analysis of intact cells showed absorbance maxima within the range typical of carotenoids $(400-550 \mathrm{~nm})$ but no evidence for bacteriochlorophyll $a$ (data not shown). Therefore, strain VP55 is presumably nonphototrophic. It is also of interest that strain VP55 was significantly restricted in its use of organic compounds. Unlike the other five Lake Vanda strains and unlike what is typical of purple nonsulfur bacteria [49], strain VP55 
was unable to catabolize sugars, alcohols, or fatty acids and used only a few organic acids as carbon and energy sources. The phylogenetic position of strain VP55 leaves open the remote possibility that besides heterotrophy, the organism may also be able to grow chemolithotrophically, for example, on $\mathrm{H}_{2}$.

The bright-yellow-pigmented strain VY55 was phylogenetically identical to Sphingobium sp. FO10, isolated from the water column of Lake Fryxell, Antarctica, and showed 99.3\% sequence identity to Sphingomonas sp. Ant17, a hydrocarbon-degrading bacterium isolated from soil near Scott Base, Antarctica; hence, these are possible sources of this organism in Lake Vanda. Interestingly, however, while some relatives of psychrotolerant strain VY55 are also adapted to cold temperatures, others are mesophilic. For example, Sphingobium rhizovicinum str. CC-FH12-1, isolated from rhizosphere soils of the fruit-bearing tree Fortunella hindsii, has a growth range of $22-37^{\circ} \mathrm{C}$ [50]. Another relative of strain VY55, Sphingomonas sp. BP-7, was isolated from Seto Inland Sea water offshore of Matsuyama, Japan [51]. In support of the phylogenetic connection between strain VY55 and the marine strain BP-7, growth of strain VY55 occurred in media containing up to $6 \% \mathrm{NaCl}$, and colonies of both strains exhibited yellow pigmentation.

\section{Conclusions}

Our research shows that although most of the Lake Vanda bacteria isolated in this study are capable of growth at subzero temperatures, optimal growth of these strains occurred from 18 to $24{ }^{\circ} \mathrm{C}$, a phenomenon that has been repeatedly observed in phylogenetically diverse bacteria isolated from other Dry Valleys lakes [16-19]. Since psychrophiles have optimal growth temperatures at or below $15{ }^{\circ} \mathrm{C}$ [52], all six Lake Vanda strains would best be described as psychrotolerant rather than psychrophilic. In addition to some measure of cold adaptation, the Lake Vanda strains demonstrated varying degrees of halotolerance, with one strain, Rhodococcus strain BYV50, capable of growth in media containing $10 \% \mathrm{NaCl}$. The broad range of halotolerance in these isolates may be a reflection of the pronounced salinity gradient within the Lake Vanda water column itself, which increases from freshwater to approximately $11 \%$ with depth (Figure 1).

Although the Lake Vanda strains described here are not optimally adapted to the $10-12{ }^{\circ} \mathrm{C}$ temperatures that occur at the depths from which they were isolated, they are nevertheless capable of growth at such temperatures and likely compete well under such conditions. The impressive versatility of these strains, characterized by their ability to grow (1) in temperatures ranging from freezing to comparatively warm, (2) in the presence or complete absence of $\mathrm{NaCl}$, and (3) at supersaturated levels of $\mathrm{O}_{2}$, suggests that these isolates are well suited to the highly stratified and varied physiochemical conditions of the Lake Vanda water column. As a final note, with the exception of the metabolically limited strain VP55, all strains showed the capacity to catabolize a wide range of carbon sources, and therefore these nutritionally versatile bacteria are likely to be important consumers in the highly oligotrophic and oxic upper waters of this unusual Dry Valley lake.

\section{Acknowledgments}

This research was supported in part by the Hodson Summer Research Institute (Indiana Wesleyan University) and a Lilly Faculty Scholarship Award (IWU) to W. Matthew Sattley. In addition, Lake Vanda water samples were obtained through the support of National Science Foundation grant 
MCB0237576 to Michael T. Madigan. Kate Winter, Garrett Garland, and Evan Nelson are acknowledged for contributions in the culture and isolation of these strains. We thank Jeanice Troutman and Lynn Illeck at the Clemson University Genomics Institute for 16S rRNA gene sequencing and Chia-ping Huang and Debby Sherman at the Purdue University Life Science Microscopy Facility for the electron micrograph of Rhodococcus sp. BYV50. We also thank the McMurdo LTER Project for Lake Vanda water column data presented in Figure 1, Petroleum Helicopters International for field support, and the McMurdo LTER limnology team for sampling assistance.

\section{Author Contributions}

Nicole A. Vander Schaaf wrote the initial manuscript draft and, along with Anna M. G. Cunningham, Chelsea L. Reeves, CodyJo K. Kraemer, Brandon P. Cluff, Lauren K. Slater, Carli J. Riester and W. Matthew Sattley, performed the experiments that contributed to this research. W. Matthew Sattley designed the experiments and supervised the research. Michael T. Madigan wrote the grant proposal that funded sample collection, and W. Matthew Sattley wrote proposals to support laboratory investigations. W. Matthew Sattley and Michael T. Madigan edited the final version of the submitted manuscript.

\section{Conflicts of Interest}

The authors declare no conflict of interest.

\section{References}

1. Spigel, R.H.; Priscu, J.C. Physical limnology of McMurdo Dry Valley Lakes. In Ecosystem Dynamics in a Polar Desert; Priscu, J.C., Ed.; American Geophysical Union: Washington, DC, USA, 1998; Volume 72, pp. 153-187.

2. Vincent, W.F.; Vincent, C.L. Factors controlling phytoplankton production in Lake Vanda $\left(77^{\circ} \mathrm{C}\right)$. Can. J. Fish. Aquat. Sci. 1982, 39, 1602-1609.

3. Lee, P.A.; Mikucki, J.A.; Foreman, C.M.; Priscu, J.C.; DiTullio, G.R.; Riseman, S.F.; de Mora, S.J.; Wolf, C.F.; Kester, L. Thermodynamic constraints on microbially mediated processes in lakes of the McMurdo Dry Valleys, Antarctica. Geomicrobiol. J. 2004, 21, 221-237.

4. Matsumoto, G.; Torii, T.; Hanya, T. Vertical distribution of organic constituents in an Antarctic Lake: Lake Vanda. Hydrobiologia 1984, 111, 119-126.

5. McKnight, D.M.; Aiken, G.R.; Andrews, E.D.; Bowles, E.C.; Harnish, R.A. Dissolved organic material in Dry Valley Lakes: A comparison of Lake Fryxell, Lake Hoare, and Lake Vanda. In Physical and Biogeochemical Processes in Antarctic Lakes, Antarctic Research Series; Green, W., Friedmann, E.I., Eds.; American Geophysical Union: Washington, DC, USA, 1993; Volume 59, pp. 119-133.

6. Vincent, W.F.; Downes, M.T.; Vincent, C.L. Nitrous oxide cycling in Lake Vanda, Antarctica. Nature 1981, 292, 618-620.

7. Canfield, D.E.; Green, W.J. The cycling of nutrients in a closed-basin Antarctic Lake: Lake Vanda. Biogeochemistry 1985, 1, 233-256. 
8. Howes, B.L.; Schlezinger, D.R.; Goehringer, D.D.; Brown-Leger, S. Carbon cycling in a redox-stratified Antarctic Lake, Lake Fryxell. Antarct. J. US 1992, 27, 263-265.

9. Takacs, C.D.; Priscu, J.C. Bacterioplankton dynamics in the McMurdo Dry Valley Lakes, Antarctica: Production and biomass loss over four seasons. Microbial Ecol. 1998, 36, 239-250.

10. Voytek, M.A.; Priscu, J.C.; Ward, B.B. The distribution and relative abundance of ammonia-oxidizing bacteria in lakes of the McMurdo Dry Valley, Antarctica. Hydrobiologia 1999, 401, 113-130.

11. Karr, E.A.; Sattley, W.M.; Jung, D.O.; Madigan, M.T.; Achenbach, L.A. Remarkable diversity of phototrophic purple bacteria in a permanently frozen Antarctic Lake. Appl. Environ. Microbiol. 2003, 69, 4910-4914.

12. Karr, E.A.; Sattley, W.M.; Rice, M.R.; Jung, D.O.; Madigan, M.T.; Achenbach, L.A. Diversity and distribution of sulfate-reducing bacteria in permanently frozen Lake Fryxell, McMurdo Dry Valleys, Antarctica. Appl. Environ. Microbiol. 2005, 71, 6353-6359.

13. Karr, E.A.; Ng, J.M.; Belchik, S.M.; Sattley, W.M.; Madigan, M.T.; Achenbach, L.A. Biodiversity of methanogenic and other Archaea in the permanently frozen Lake Fryxell, Antarctica. Appl. Environ. Microbiol. 2006, 72, 1663-1666.

14. Glatz, R.E.; Lepp, P.W.; Ward, B.B.; Francis, C.A. Planktonic microbial community composition across steep physical/chemical gradients in permanently ice-covered Lake Bonney, Antarctica. Geobiology 2006, 4, 53-67.

15. Kong, W.; Dolhi, J.M.; Chiuchiolo, A.; Priscu, J.; Morgan-Kiss, R.M. Evidence of form II RubisCO $(c b b M)$ in a permanently ice-covered Antarctic Lake. FEMS Microbiol. Ecol. 2012, 82, 491-500.

16. Sattley, W.M.; Madigan, M.T. Isolation, characterization, and ecology of cold-active, chemolithotrophic, sulfur-oxidizing bacteria from perennially ice-covered Lake Fryxell, Antarctica. Appl. Environ. Microbiol. 2006, 72, 5562-5568.

17. Sattley, W.M.; Madigan, M.T. Cold-active acetogenic bacteria from surficial sediments of perennially ice-covered Lake Fryxell, Antarctica. FEMS Microbiol. Lett. 2007, 272, 48-54.

18. Sattley, W.M.; Madigan M.T. Temperature and nutrient induced responses of Lake Fryxell sulfate-reducing prokaryotes and description of Desulfovibrio lacusfryxellense, sp. nov., a pervasive, cold-active, sulfate-reducing bacterium from Lake Fryxell, Antarctica. Extremophiles 2010, 14, 357-366.

19. Clocksin, K.M.; Jung, D.O.; Madigan, M.T. Cold-active chemoorganotrophic bacteria from permanently ice-covered Lake Hoare, McMurdo Dry Valleys, Antarctica. Appl. Environ. Microbiol. 2007, 73, 3077-3083.

20. Sattley, W.M.; Jung, D.O.; Madigan, M.T. Psychrosinus fermentans gen. nov., sp. nov., a lactate-fermenting bacterium from near-freezing oxycline waters of a meromictic Antarctic Lake. FEMS Microbiol. Lett. 2008, 287, 121-127.

21. Stingl, U.; Cho, J.C.; Foo, W.; Vergin, K.L.; Lanoil, B.; Giovannoni, S.J. Dilution-to-extinction culturing of psychrotolerant planktonic bacteria from permanently ice-covered lakes in the McMurdo Dry Valleys, Antarctica. Microbial Ecol. 2008, 55, 395-405.

22. Mondino, L.J.; Asao M.; Madigan, M.T. Cold-active halophilic bacteria from the ice-sealed Lake Vida, Antarctica. Arch. Microbiol. 2009, 191, 785-790. 
23. Meyer, G.H.; Morrow, M.B.; Wyss, O.; Berg, T.E.; Littlepage J.L. Antarctica: The microbiology of an unfrozen saline pond. Science 1962, 138, 1103-1104.

24. Kriss, A.E.; Mitskevich, I.N.; Rozanova, E.P.; Osnitskaya, L.K. Microbiological investigations of Lake Vanda (Antarctica). Microbiology 1976, 45, 917-922.

25. Takii, S.; Konda, T.; Hiraishi, A.; Matsumoto, G.I.; Kawano, T.; Torii, T. Vertical distribution in and isolation of bacteria from Lake Vanda: An Antarctic Lake. Hydrobiologia 1986, 135, 15-21.

26. Nagashima, H.; Nishikawa, J.; Matsumoto, G.I.; Iizuka, H. Characterization and habitats of bacteria and yeasts isolated from Lake Vanda in Antarctica. Proc. NIPR Symp. Polar Biol. 1990, 3, 190-200.

27. Bratina, B.J.; Stevenson, B.S.; Green, W.J.; Schmidt, T.M. Manganese reduction by microbes from oxic regions of the Lake Vanda (Antarctica) water column. Appl. Environ. Microbiol. 1998, 64, 3791-3797.

28. Tregoning, G.S.; Kempher, M.L.; Jung, D.O.; Samarkin, V.A.; Joye, S.B.; Madigan, M.T. A halophilic bacterium inhabiting the warm, $\mathrm{CaCl}_{2}$-rich brine of the perennially ice-covered Lake Vanda, McMurdo Dry Valleys, Antarctica. Appl. Environ. Microbiol. 2015, 81, 1988-1995.

29. Trüper, H.G.; Schlegel, H.G. Sulphur metabolism in Thiorhodaceae. I. Quantitative measurements on growing cells of Chromatium okenii. Antonie van Leeuwenhoek 1964, 30, $225-238$.

30. Lyons, W.B.; Welch, K.A. McMurdo Long-Term Ecological Research Database. McMurdo Dry Valleys Long-Term Ecological Research, Albuquerque, NM. Available online: http://www.mcmlter.org (assessed on 14 July 2015).

31. Reasoner, D.J.; Geldreich, E.E. A new medium for the enumeration and subculture of bacteria from potable water. Appl. Environ. Microbiol. 1985, 49, 1-7.

32. Zimbro, M.J.; Power, D.A.; Miller, S.M.; Wilson, G.E.; Johnson, J.A. Difco \& BBL Manual: Microbiological Culture Media, 2nd ed.; Becton, Dickinson and Company: Sparks, MD, USA, 2009; Volume 520, pp. 441-442.

33. Maneval, W.E. Staining bacteria and yeasts with acid dyes. Biotech. Histochem. 1941, 16, $13-19$.

34. Wahlund, T.M.; Woese, C.R.; Castenholz, R.W.; Madigan, M.T. A thermophilic green sulfur bacterium from New Zealand hot springs, Chlorobium tepidum sp. nov. Arch. Microbiol. 1991, 156, 81-90.

35. Okonechnikov, K.; Golosova, O.; Fursov, M. Unipro UGENE: A unified bioinformatics toolkit. Bioinformatics 2012, 28, 1166-1167.

36. Edgar, R.C. MUSCLE: Multiple sequence alignment with high accuracy and high throughput. Nucleic Acids Res. 2004, 32, 1792-1797.

37. Tamura, K.; Peterson, D.; Peterson, N.; Stecher, G.; Nei, M.; Kumar, S. MEGA5: Molecular Evolutionary Genetics Analysis using maximum likelihood, evolutionary distance, and maximum parsimony methods. Mol. Biol. Evol. 2011, 28, 2731-2739.

38. Altschul, S.F.; Gish, W.; Miller, W.; Myers, E.W.; Lipman, D.J. Basic Local Alignment Search Tool. J. Mol. Biol. 1990, 215, 403-410.

39. Cole, J.R.; Wang, Q.; Cardenas, E.; Fish, J.; Chai, B.; Farris, R.J.; Kulam-Syed-Mohideen, A.S.; McGarrell, D.M.; Marsh, T.; Garrity, G.M.; Tiedje, J.M. The Ribosomal Database Project: Improved alignments and new tools for rRNA analysis. Nucleic Acids Res. 2009, 37, 141-145. 
40. Euzéby, J.P. List of Bacterial Names with Standing in Nomenclature: A folder available on the internet. Int. J. Syst. Bacteriol. 1997, 47, 590-592.

41. Tamura, K.; Nei, M. Estimation of the number of nucleotide substitutions in the control region of mitochondrial DNA in humans and chimpanzees. Mol. Biol. Evol. 1993, 10, 512-526.

42. Buck, J.D. Nonstaining $(\mathrm{KOH})$ method for determination of Gram reactions of marine bacteria. Appl. Environ. Microbiol. 1982, 44, 992-993.

43. Mergaert, J.; Verhelst, A.; Cnockaert, M.C.; Tan, T.-L.; Swings, J. Characterization of facultative oligotrophic bacteria from polar seas by analysis of their fatty acids and 16S rDNA sequences. Syst. Appl. Microbiol. 2001, 24, 98-107.

44. Shivaji, S.; Begum, Z.; Shiva Nageswara Rao, S.S.; Vishnu Vardhan Reddy, P.V.; Manasa, P.; Sailaja, B.; Prathiba, M.S.; Thamban, M.; Krishnan, K.P.; Singh, S.M.; et al. Antarctic ice core samples: Culturable bacterial diversity. Res. Microbiol. 2013, 164, 70-82.

45. Fritz, I.; Strömpl, C.; Nikitin, D.I.; Lysenko, A.M.; Abraham, W.-R. Brevundimonas mediterranea sp. nov., a non-stalked species from the Mediterranean Sea. Int. J. Syst. Evol. Microbiol. 2005, 55, 479-486.

46. Lu, Z.; An, X.; Zhang, W. Isolation and phylogenetic analysis of chromium(VI) reducing bacteria of a magnetite mine drainage from Hebei China. Modern Appl. Sci. 2011, 5, 113-118.

47. Zakhia, F.; Jeder, H.; Willems, A.; Gillis, M.; Dreyfus, B.; de Lajudie, P. Diverse bacteria associated with root nodules of spontaneous legumes in Tunisia and first report for nifH-like gene within the genera Microbacterium and Starkeya. Microbial Ecol. 2006, 51, 375-393.

48. De Meyer, S.E.; Van Hoorde, K.; Vekeman, B.; Braeckman, T.; Willems, A. Genetic diversity of rhizobia associated with indigenous legumes in different regions of Flanders (Belgium). Soil Biol. Biochem. 2011, 43, 2384-2396.

49. Madigan, M.T.; Jung, D.O. An overview of purple bacteria: Systematics, physiology, and habitat. In The Purple Phototrophic Bacteria; Hunter, C.N., Daldal, F., Thurnauer, M.C., Beatty, J.T., Eds.; Springer: Dordrecht, the Netherlands, 2009; pp. 1-15.

50. Young, C.-C.; Arun, A.B.; Kämpfer, P.; Busse, H.-J.; Lai, W.-A.; Chen, W.-M.; Shen, F.-T.; Rekha, P.D. Sphingobium rhizovicinum sp. nov., isolated from rhizosphere soil of Fortunella hindsii (Champ. ex Benth.) Swingle. Int. J. Syst. Evol. Microbiol. 2008, 58, 1801-1806.

51. Sakai, K.; Yamanaka, H.; Moriyoshi, K.; Oshmoto, T.; Ohe, T. Biodegradation of bisphenol A and related compounds by Sphingomonas sp. strain BP-7 isolated from seawater. Biosci. Biotech. Bioch. 2007, 71, 51-57.

52. Helmke, E.; Weyland, H. Psychrophilic versus psychrotolerant bacteria-Occurrence and significance in polar and temperate marine habitats. Mol. Cell. Biol. 2004, 50, 553-561.

(C) 2015 by the authors; licensee MDPI, Basel, Switzerland. This article is an open access article distributed under the terms and conditions of the Creative Commons Attribution license (http://creativecommons.org/licenses/by/4.0/). 